\title{
MICROENCAPSULATED MIXTURE OF FISH OIL AND FORTIFIED IN ICE CREAM
}

\author{
Pontjo Tri Andajani \\ National Animal Husbandry Training Centre, Batu, East Java, Indonesia
}

Diterima 20 Juli2016; diterima pasca revisi 29 Juli 2016

Layak diterbitkan 1 Oktober 2016

\begin{abstract}
In recent years there has been considerable efforts to rearrange fatty acids composition of dairy products to improve the long-term health of consumers. One of the efforts is to fortify essential fatty acids in ice cream. The objective of this study was to find out the fatty acids profile of either Selaroides spp, Clarias sp and Thunnus sp fish oil, microencapsulated fish oil and ice cream fortified with this fish oil mixture. Selaroides spp. Clarias sp and Thunnus sp used as raw material were obtained from Palu, Central Sulawesi. The study was caried out using Nested Block Design as the experimental design. The microencapsulated fish oil was prepared using freeze drying and spray drying method. The variables measured were fatty acids profile, microencapsulated fish oil and ice cream fortified with microencapsulated fish oil. The research results showed that SFA, MUFA and PUFA contents of fish oil mixture of Selaroides spp and Clarias sp using freeze drying method were $53.74 \%, 32.20 \%$ and $1.91 \%$, while using spray drying method were $61.30 \%, 38.70 \%$ and $0 \%$ (not detected), respectively. It can be concluded that freeze drying method from the point of view of total PUFA is the best method for mincroencapsulation process of this fish oil mixture. Fortification of $15 \mathrm{~g}$ $(w / w)$ microencapsulated fish oil in ice cream could reduced SFA and increased the MUFA and PUFA.
\end{abstract}

Key words: fish oil, microencapsulation, spray drying, freeze drying, ice cream.

\section{INTRODUCTION}

Ice cream is a dairy product made by the process of freezing and agitation on materials consisting of milk and dairy products, sweeteners, stabilizers, emulsifiers, as well as a flavor enhancer. Currently ice cream is a food product that is popular in the community and it usually consumed as a snack (dessert), but the ice cream fortified with essential fatty acids like omega 3, omega 6 and omega 9 are still rare. Essential fatty acids are fats that are needed by the body and have the function to support the cardiovascular system, reproductive, immune and nervous system. Another function of essential fatty acids also can produce prostaglandin that can regulate the body functions such as heart rate, blood pressure, blood clotting, fertility, conception and plays a role in immune function by regulating inflammation and encouraging the body to fight infection. Essential fatty acids can not be synthesized by the body and must be obtained from food. Deficiency of essential fatty acid can affect the health conditions such as heart disease, cancer, insulin resistance, lupus, 
schizophrenia, depression, postpartum depression, premature aging, stroke, obesity, diabetes, arthritis, and alzhemeir diseases. One source of essential fatty acids is fish oil. Fish oil is the main source of long chain polyunsaturated fatty acids (LC PUFA) omega-3, especially EPA (eicosapentaenoic acid) and DHA (docosahexaenoic acid) which important for health. The positive influence of omega-3 fatty acids on health can prevent heart disease and cancer, and can improve the function of the brain and retina of the eye (Banning, 2005). According to the mixture between trevally fish oil and catfish can produce omega-3, omega- 6 , and omega- 9 were $9.7,0.06$, and $42.81 \%$, respectively (Gobel, 2012). Fatty acids are highly susceptible to oxidation, so it takes a process before fatty acid fortified to food products, and alternative processes that can be used is microencapsulation.

Milk fortified with fish oil at the level of $15 \mathrm{~g} / \mathrm{kg}$ did not affect the smell of it (Let et al., 2003). Microencapsulation of $2 \%$ salmon oil which added to the strawberry yogurt before pasteurization and homogenization can improve eicosapentaenoic acid and docosahexaenoic acid (Estrada, 2011). The addition of lemuru fish oil in yogurt of $0.5 \%, 1 \%, 1.5 \%$ and $2 \%$ can improve the nutritional quality of the product, especially omega 3 and omega 6 fatty acids (Astuti dan Setyawardani, 2006). The research aimed to study the fatty acid profile of ice cream has been fortified with microencapsulated mixture between fish oil of trevally (Selaroides spp) and catfish (Clarias sp).

\section{MATERIALS AND METHODS}

\section{Sample}

Three kind of non-economical fish such as Trevally (Selaroides spp), Catfish (Clarias sp) and Tuna (Thunnus $s p$ ) were obtained from sea water of Palu, Central
Sulawesi Province. The chemical agents used for the analysis were hexane, acetone, ethanol, diethyl ether, acetic acid, formic acid, petroleum ether, $\mathrm{KOH}$ and $\mathrm{Na}_{2} \mathrm{SO}_{4}$ anhydrous (Sigma - Aldrich).

\section{Experimental Design}

This research was design using Nested Block Design with two treatments of microencapsulation method, namely freeze drying method (F1) and spray drying method (F2), respectively. The microcapsules of fish oil were obtained from a mixture of trevally and catfish oil (M1) and tuna fish oil (M2). The omega 3, 6 , and 9 from the microcapsules of fish oil was determined using Gas Chromatography (GC) (SHIMADZU-FID) (AOAC, 2000).

\section{Fatty Acid, SFA, MUFA, and PUFA Profile from Trevally, Catfish, and Tuna Oil}

Trevally and catfish oil used in this study was extracted by wet rendering method, while tuna fish oil using solvent method (AOCS, 1990). Subsequently, the fatty acids profiles from extracted fish oil were analyzed using Gas Chromatography (GC) (SHIMADZU-FID) (AOAC, 2000). According to the fish oil analysis the content of PUFA and MUFA, a mixture of trevally and catfish oil with ratio 1:1 were adopted for the next step of this research.

\section{Microencapsulation of Fish Oils and Fatty Acid Profile Analysis, SFA, MUFA and PUFA of Microcapsules Fish Oil}

One encapsulating material used in this research was sodium caseinate with ratio 6:1 of sodium caseinate and fish oil (Estiasih dkk., 2008). Freeze drying and spray drying (Buchi Mini Spray Drier B290) method were obtained to encapsulate trevally fish oil mixed with catfish oil and tuna fish oil. Spray drying was achieved by preparation of emulsion material, homogenizing of the ingredient and spraying the emulsion into the chamber. 
The emulsion preparation, coatings is dissolved into the water, then coating materials and ingredients were mixed up into a homogeneous emulsion. The homogenized emulsions were spray dried using inlet and outlet temperature of 130 and $72^{\circ} \mathrm{C}$, with the flow rate of $5 \mathrm{ml} / \mathrm{sec}$, respectively. For microencapsulation by freeze drying method was employed using freezer dryer scanvaccoolsave. Samples were closed with aluminium foil cover to protect samples against light and stored at freeze temperature for 24 hours, then were kept at freeze dryer for 40 hours. Moreover, the fatty acid profile, SFA, MUFA, and PUFA in microcapsules was characterized using Gas Chromatography (AOAC, 2000).

\section{Analysis of Fatty Acid Profile, SFA, MUFA, and PUFA of Ice Cream Fortified with Microencapsulated Fish Oil}

The cow's milk for ice cream was obtained from Agricultural Training Center, Batu Malang. Further, ice cream was characterized for fatty acid profile, SFA, MUFA, and PUFA using GC (AOAC, 2000). Ice cream was then fortified with microencapsulated fish oil using three treatments, i.e $15 \mathrm{~g} / \mathrm{kg} ; 20 \mathrm{~g} / \mathrm{kg}$ and $25 \mathrm{~g} / \mathrm{kg}$. The best treatment was then selected (De Garmo, 1984) and analyzed the fatty acids profile, SFA, MUFA and PUFA using GC, as well as organoleptic testing.

\section{Statistical Analysis}

The descriptive analysis was applied to the data obtained from the profile of fatty acid, PUFA, MUFA, and SFA. Analysis of variance was performed using SPSS software to evaluate the effect of the parameters studied. Differences among mean values were examined using Test Honestly Significant Difference (HSD) at the $\mathrm{p}<0.05$ significance level. The best treatment was determined. Mathematic model was used to analyze the effect of microencapsulation methods and parameters studied (omega 3, 6, and 9): $\mathrm{Y}_{\mathrm{ijk}}=\mu+\mathrm{t}_{\mathrm{i}}+\beta_{(\mathrm{ij})}+\mathrm{E}_{\mathrm{ijk}}$.

\section{RESULTS AND DISCUSSION}

\section{Fatty Acids Composition of the Trevally, Catfish, and Tuna Fish Oil}

Table 1 shows the composition of fatty acids in trevally, catfish and tuna fish oil. The fatty acids produced by these fish oil were saturated fatty acids (SFA), monounsaturated fatty acids (MUFA) and polyunsaturated fatty acids (PUFAs). Further, result shows that the dominant polyunsaturated fatty acids found are eicosatrionic, linoleic and docosahecsanoic acid, while the predominant saturated fatty acid in trevally, catfish and tuna fish oilis palmitic acid of which 33.03, 24.99 and $26.53 \%$, respectively. Palmitic and palmitoleic acids are the fatty acid dominant in Clariasgariepinus, Tilapia zillii, Pentanemusquinquarius, Pseudotolithustypus in the sea water of Lagos, Nigeria (Adesola, 2011). Several factors affecting of fatty acid composition are climate, temperature, rain fall, species, sex, weight, size and feed (Adesola, 2011; Nowsad et al., 2012).

Furthermore, the omega 3, 6 and 9 of trevally, catfish and tuna fish oil are shown in Table 2. In all of the fishs oil, trevally fish produced omega 3, 6 and 9 of $13.48,11.77$ and $15.50 \%$, respectively. For the later the mixture of travelly and catfish oil were chosen for further research studyto increase the accumulation of omega 3,6 and 9. The mixture of trevally and catfish at ratio $1: 1$, led to the omega 3,6 and 9 , approximately 5.25, 20.61 and $35.52 \%$, respectively (Gobel, 2012). 
Table 1. Fatty Acids Composition of Trevally (Selaroides spp), Catfish (Clarias sp), and Tuna Fish Oil (Thunnus sp)

\begin{tabular}{|c|c|c|c|c|c|c|c|}
\hline Fatty Acid & \multicolumn{2}{|c|}{ Selaroidesspp } & \multicolumn{3}{|c|}{ Clariassp } & \multicolumn{2}{|c|}{ Thunnussp } \\
\hline Caproic & 0.007 & \pm 0.006 & 0 & & 0 & 0 & 0 \\
\hline Caprilic & 0.003 & \pm 0.001 & 0.046 & \pm & 0.003 & 0.124 & \pm 0.002 \\
\hline Lauric & 0.106 & \pm 0.035 & 1.963 & \pm & 0.047 & 0 & 0 \\
\hline Tridecanoic & 0.093 & \pm 0.014 & 0.009 & \pm & 0.002 & 0.080 & \pm 0.010 \\
\hline Myristoleic & 0.030 & \pm 0.004 & 0.053 & \pm & 0.001 & 0 & 0 \\
\hline Myristic & 5.916 & \pm 0.943 & 1.999 & \pm & 0.038 & 4.483 & \pm 0.072 \\
\hline Pentadecanoic & 1.689 & \pm 0.287 & 0.210 & \pm & 0.006 & 1.348 & \pm 0.022 \\
\hline Palmitoleic & 8.183 & \pm 0.581 & 4.956 & \pm & 0.072 & 7.884 & \pm 0.079 \\
\hline Palmitic & 33.026 & \pm 0.865 & 24.999 & \pm & 0.416 & 26.528 & \pm 0.470 \\
\hline Heptadekanoic & 0.150 & \pm 0.020 & 0 & & 0 & 0.888 & \pm 0.010 \\
\hline Cis- & & \pm 0.419 & & & 0 & & \pm 0.027 \\
\hline heptadekanoic & 2.361 & & 0 & & & 1.447 & \\
\hline Oleic & 15.502 & \pm 0.569 & 34.967 & \pm & 0.488 & 19.746 & \pm 0.038 \\
\hline Stearic & 3.013 & \pm 0.528 & 22.955 & \pm & 1.351 & 2.844 & \pm 0.039 \\
\hline Linoleic & 10.241 & \pm 0.499 & 6.294 & \pm & 0.102 & 6.756 & \pm 0.158 \\
\hline Arakidat & 6.304 & \pm 1.025 & 0 & & 0 & 4.571 & \pm 0.072 \\
\hline Linolenic & 1.525 & $\pm 0.2 ; 30$ & 0.866 & \pm & 0.728 & 0.759 & \pm 0.012 \\
\hline Heneicosanoic & 0.316 & \pm 0.047 & 0 & & 0 & 21.771 & \pm 0.095 \\
\hline Euric & 0.261 & \pm 0.041 & 0.321 & \pm & 0.516 & 0 & \pm 0 \\
\hline Eicosatrinoic & 11.383 & \pm 0.712 & 0.118 & \pm & 0.041 & 0.128 & \pm 0.013 \\
\hline Arachidonic & 1.530 & \pm 0.257 & 0 & & 0 & 0.500 & \pm 0.011 \\
\hline Tricosanoic & 0.584 & \pm 0.096 & 0.002 & \pm & 0.002 & 0 & \pm 0 \\
\hline Eicopentanoic & 0.231 & \pm 0.037 & 0.004 & \pm & 0.004 & 0.237 & \pm 0.018 \\
\hline Nervonic & 0.689 & \pm 0.151 & 0.037 & \pm & 0.037 & 0 & \pm 0 \\
\hline Docohexsanoic & 0.336 & \pm 0.055 & 0.003 & \pm & 0.003 & 0 & \pm 0 \\
\hline SFA & & 259 & & .95 & & & 426 \\
\hline MUFA & & 685 & & .92 & & & \\
\hline PUFA & & 246 & & 285 & & & 80 \\
\hline
\end{tabular}

Table 2. The Composition of omega 3, omega 6 and omega 9 from Trevally (Selaroides spp), Catfish (Clarias sp), and Tuna Fish Oil (Thunnus sp)

\begin{tabular}{lrrr}
\hline Fish oil & Omega 3(\%) & Omega 6 (\%) & Omega 9 (\%) \\
\hline Trevally(Selaroidesspp) & $13.48 \pm 0.34$ & $11.77 \pm 0.72$ & $15.50 \pm 0.48$ \\
Catfish(Clariassp) & $0.99 \pm 0.17$ & $6.29 \pm 0.10$ & $34.96 \pm 0.49$ \\
Tuna Fish Oil ( Thunnussp) & $1.12 \pm 0.03$ & $7.25 \pm 0.15$ & $19.75 \pm 0.04$ \\
\hline
\end{tabular}




\section{Microencapsulation of Fish Oil on the Fatty Acids, Omega 3, 6 and 9 Composition}

Results of polyunsaturated (PUFA), monounsaturated (MUFA), and saturated (SFA) fatty acids from microencapsulation of trevally mixed with catfish oil and tuna fish oil are presented in Table 3. As shown in Table 3, the predominant SFA produced by microencapsulation of trevally mixed with catfish oil were palmitic and stearic acid of 41.05 and $13.90 \%$ using freeze drying method, respectively. Then a slower rate was noted when spray drying was achieved for microencapsulation method of 40.72 and $12.49 \%$, respectively, whereas palmitic acid of 47.87 and $44.97 \%$, respectively were achieved when tuna fish oil was microencapsulated using freeze drying and spray drying method. Therefore, the spray drying method could effectively be employed as a microencapsulation method and led to higher oleic acid of trevally mixed with catfish oil and tuna fish oil approximately 38.70 and $18.86 \%$, respectively. The highest SFA production was obtained in tuna fish oil using freeze and spray drying microencapsulation method, while the highest MUFA occurred in trevally mixed with catfish oil using spray drying microencapsulation method. Therefore, it is could employed as a microencapsulation method for tuna fish oil since most of fatty acid present are monounsaturated fatty acid (MUFA).

Additionally, spray drying is one of the most commonly used for fish oil microencapsulation and drying technologies because the process is flexible and produces good quality powder. The disadvantage of this technology is the high temperature conditions necessary for drying and access to air (Heinzelmann et al., 2000). Moreover, parts of the product during drying may adhere to the surface of the capsules, which presents potential for oxidation and changes in the flavor balance of the finished food products.
Otherwise microencapsulation using freeze drying method could effectively led to increase the concentration of PUFA i.e linoleic, linolenic, arachidonic and eikosatrionic acid in trevally mixed with catfish oil and tuna fish oil from undetectable to $1.19 \%$ and from $1.65 \%$ to $2.29 \%$, respectively. Therefore, drying processes at low temperature such as freeze drying could be an alternative for microencapsulation of fish oil, since it is essential to protect fish oil against oxidation due to the high susceptibility to oxidation of the highly unsaturated PUFA. PUFA plays an important role in human health body and recognized as essential in the diet (Kolanowski et al., 2006; Drusch et al., 2008; Beindoeff et al., 2010).

In Figure $1 \mathrm{~A}, 21$ peaks were detected in trevally fish oil mixed with catfish oil. In comparison with chromatograms obtained using standard, it was found that these oil contained saturated fatty acid (SFA), monounsaturated fatty acid (MUFA) and polyunsaturated fatty acid (PUFA) with the concentrations were found to be $53.74,32.20$ and $1.19 \%$, respectively. Additionally, results showed that PUFA component in these fish oil were linoleic, linolenic, and arachidic and eicosatrionic acids. The results are in good agreement with that reported by literature, who found that the fatty acid detected in Clariasgariepinusfish oil was MUFA approximately $26 \%$, respectively (Adesola, 2011). The major component of fatty acid in menheden and salmon fish oil were MUFA and SFA, approximately $24-29 \%$ and 21$34 \%$, respectively (Beindoeff et al., 2010).

Moreover, the fatty acids compositions in tuna fish oil using freeze drying method are shown in Figure $1 \mathrm{~B}$. According to Figure $1 \mathrm{~B}$, total 16 fatty acids compound were identified. It was observed that the major fatty acids produced by tuna fish oil were palmitic acid $(47.87 \%)$, stearic acid (15.57\%) and oleic acid (15.59\%). 
Monounsaturated fatty acids (MUFA) were oil and tench fish oil of 35.9, 35.8 and $38.3 \%$, respectively (Luczynska et al., 2012). Monounsaturated fatty acids (MUFA) were present in Malabar Red Snapper fish oil, trevally fish oil and Spain Mackarel at the concentrations of $141.8,286.8,70.6$ $\mathrm{mg} / 100 \mathrm{~g}$, while for polyunsaturated fatty found in rainbow trout fish oil, bream fish acids (PUFA) at the concentrations of 724.7 , 869.6 , and $322.8 \mathrm{mg} / 100 \mathrm{~g}$, respectively (Nurnaida et al., 2013). The differences of fatty acids composition are greatly affected by species, season, and water condition (Steffens et al., 2005).

Table 3. The Composition of Fatty Acids, Omega 3, 6 and 9 in Trevally fish (Selaroides spp) Mixed with Catfish (Clarias sp) Oil and Tuna Fish Oil (Thunnus sp) (\% Total Fatty Acids)

\begin{tabular}{|c|c|c|c|c|c|c|c|c|c|}
\hline \multirow{2}{*}{$\begin{array}{l}\text { Fatty Acid } \\
\text { Caproic }\end{array}$} & \multicolumn{2}{|c|}{$\begin{array}{c}\text { Freeze } \\
\text { DryingTrevally } \\
\text { fish mixed with } \\
\text { Catfish }\end{array}$} & \multicolumn{2}{|c|}{$\begin{array}{c}\text { Freeze Drying Tuna } \\
\text { Fish Oil }\end{array}$} & \multicolumn{2}{|c|}{$\begin{array}{c}\text { Spray } \\
\text { DryingTrevally fish } \\
\text { mixed with Catfish }\end{array}$} & \multicolumn{3}{|c|}{$\begin{array}{c}\text { Spray Drying Tuna } \\
\text { Fish Oil }\end{array}$} \\
\hline & 0.001 & \pm 0.004 & 0 & 0 & 0 & 0 & 0 & & 0 \\
\hline Caprilic & 0.024 & \pm 0.013 & 0 & 0 & 0 & 0 & 0.430 & \pm & 0.042 \\
\hline Capric & 0.008 & \pm 0.001 & 0 & 0 & 0 & 0 & 0 & \pm & 0 \\
\hline Lauric & 0.238 & \pm 0.048 & 0.070 & \pm 0.001 & 0 & 0 & 0.411 & \pm & 0.194 \\
\hline Myristoleic & 0.037 & \pm 0.006 & 0.032 & \pm 0.006 & 0 & 0 & 0 & & 0 \\
\hline Myristic & 4.565 & \pm 0.124 & 6.079 & \pm 0.182 & 3.958 & \pm 0.401 & 6.350 & \pm & 0.155 \\
\hline Pentadecanoic & 1.362 & \pm 0.018 & 2.084 & \pm 0.069 & 0 & 0 & 1.588 & \pm & 0.063 \\
\hline Palmitoleic & 6.238 & \pm 0.303 & 6.119 & \pm 0.037 & 2.890 & \pm 0.084 & 5.874 & \pm & 0.880 \\
\hline Palmitic & 41.052 & \pm 0.484 & 47.874 & \pm 1.032 & 40.724 & \pm 1.065 & 44.972 & \pm & 1.163 \\
\hline Heptadecanoic & 1.836 & \pm 0.014 & 2.966 & \pm 0.023 & 0 & 0 & 2.145 & \pm & 0.088 \\
\hline Oleic & 25.965 & \pm 0.711 & 15.585 & \pm 0.990 & 38.701 & \pm 0.383 & 18.863 & \pm & 0.870 \\
\hline Stearic & 13.900 & \pm 0.240 & 15.566 & \pm 0.002 & 12.492 & \pm 0.451 & 15.475 & \pm & 0.346 \\
\hline Linoleic & 0.032 & \pm 0.007 & 0.048 & \pm 0.008 & 0 & 0 & 0 & & 0 \\
\hline Arachidonic & 1.886 & \pm 0.006 & 0.842 & \pm 0.233 & 1.242 & \pm 0.354 & 0.709 & \pm & 0.019 \\
\hline Linolenic & 0.554 & \pm 0.010 & 1.037 & \pm 0.006 & 0 & 0 & 0.826 & \pm & 0.031 \\
\hline Behenic & 0.021 & \pm 0.001 & 0.022 & \pm 0.001 & 0.610 & \pm 0.030 & 0.012 & \pm & 0.001 \\
\hline Eicosatrinoic & 0.176 & \pm 0.001 & 0.422 & \pm 0.032 & 0 & 0 & 0.317 & \pm & 0.014 \\
\hline Euric & 0.176 & \pm 0.001 & 0 & 0 & 0 & 0 & 2.887 & \pm & 0.207 \\
\hline Arachidonic & 0.429 & \pm 0.003 & 0.787 & \pm 0.025 & 0 & 0 & 0.509 & \pm & 0.010 \\
\hline Lignoceric & 0.165 & \pm 0.001 & 0.342 & \pm 0.008 & 0 & 0 & 0.013 & \pm & 0.013 \\
\hline Nervonic & 0.280 & \pm 0.002 & 0.750 & \pm 0.002 & 0 & 0 & 0.051 & \pm & 0.051 \\
\hline SFA & 53.741 & & 75.338 & & 61.306 & & 67.909 & & \\
\hline MUFA & 32.203 & & 21.704 & & 41.510 & & 24.737 & & \\
\hline PUFA & 1.191 & & 2.294 & & 0 & & 1.652 & & \\
\hline
\end{tabular}

Freeze drying is proved to be the best drying process to produce microcapsules, since it contained the highest omega 3 and 6 . It is also obvious that omega 3 and 6 in tuna fish oil were considered statistically significant $(\mathrm{p}<0.01)$ compared with travelly mixed with catfish oil using freeze drying and spray drying method. Typical fish oil microencapsulation is usually based on the formation of ordinary emulsion in which fish oil droplets are emulsified using combination of matrices 
and then spray dried ir freeze dried to produce microcapsules. Encapsulated materials are generally used for microencapsulation is sodium caseinate. Sodium caseinate could be employed as encapsulan to produce stable microcapsules (Estiasih dkk. 2008). Sodium caseinate is a protein-based coating that is able to protect against oxidation reaction, extreme storage conditions, and has a fairly high efficiency of the microcapsules (Hogan et al., 2001; Day et al., 2007).

Moreover, freeze drying method showed the best result for producing encapsulated fish oil in the form of microcapsules (Heinzelmann et al., 2000). While the stability of omega 3 in fish oil encapsulated was influenced by the best combination of material and the type of encapsulan drying method in use (Anwar et al., 2011).

Intensity
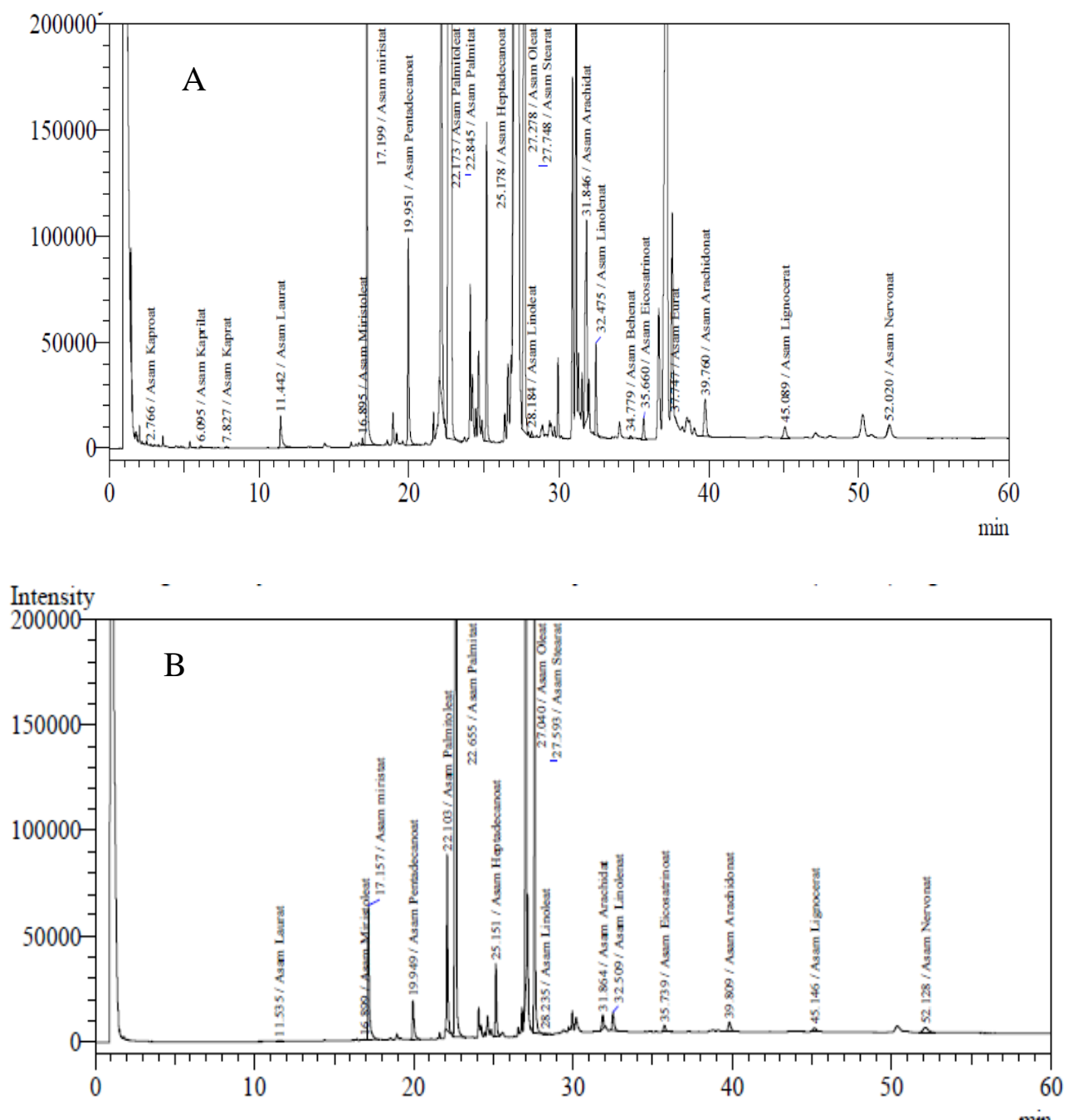

Figure 1. Chromatogram of Fatty Acids Composition in Microencapsulation of Trevally Fish Oil Mixed with Catfish Oil (A); Tuna Fish Oil (B) using Freeze Drying Method 
Table 4. The Profile of Fatty Acids of Fortified Ice Cream (15 g / kg) with Microcapsules Mixture between Trevally and Catfish Fish Oil (\% Total Fatty Acids)

\begin{tabular}{|c|c|c|c|c|c|}
\hline Fatty Acid & \multicolumn{2}{|c|}{ Not fortified ice cream } & \multicolumn{3}{|c|}{ Fortified ice cream } \\
\hline Caproic & 0.380 & \pm 0.008 & 0 & \pm & 0 \\
\hline Caprilic & 1.016 & \pm 0.103 & 0 & \pm & 0 \\
\hline Capric & 0.014 & \pm 0.003 & 0.029 & \pm & 0.001 \\
\hline Lauric & 2.164 & $\pm \quad 0.021$ & 1.742 & \pm & 0.029 \\
\hline Tridecanoic & 0 & 0 & 0.041 & \pm & 0.001 \\
\hline Myristoleic & 0.789 & \pm 0.012 & 0.030 & \pm & 0.001 \\
\hline Myristic & 10.159 & \pm 0.133 & 3.941 & \pm & 0.050 \\
\hline Pentadecanoic & 1.214 & \pm 0.016 & 1.009 & \pm & 0.012 \\
\hline Palmitoleic & 1.295 & $\pm \quad 1.116$ & 4.633 & \pm & 0.077 \\
\hline Palmitic & 36.293 & $\pm \quad 0.443$ & 26.466 & \pm & 0.307 \\
\hline Heptadecanoic & 0.687 & $\pm \quad 0.009$ & 1.332 & \pm & 0.015 \\
\hline Oleic & 27.228 & \pm 1.055 & 33.799 & \pm & 0.382 \\
\hline Stearic & 17.182 & \pm 0.186 & 9.660 & \pm & 0.111 \\
\hline Linoleic & 0.633 & $\pm \quad 0.019$ & 0.153 & \pm & 0.002 \\
\hline Arachidonic & 0.251 & $\pm \quad 0.008$ & 1.511 & \pm & 0.021 \\
\hline Linolenic & 0.189 & \pm 0.059 & 1.164 & \pm & 0.016 \\
\hline Behenic & 0.020 & $\pm \quad 0.001$ & 0 & & 0 \\
\hline Euric & 0.015 & $\pm \quad 0.001$ & 10.546 & \pm & 0.122 \\
\hline Eicosatrinoic & 0.034 & $\pm \quad 0.002$ & 1.620 & \pm & 0.017 \\
\hline Arachidonic & 0.077 & $\pm \quad 0.001$ & 0.313 & \pm & 0.003 \\
\hline Lignoceric & 0.030 & $\pm \quad 0.001$ & 0 & \pm & 0 \\
\hline Eicopentanoic & 0 & 0 & 0.090 & \pm & 0.001 \\
\hline Nervonic & 0.032 & $\pm \quad 0.024$ & 0.223 & \pm & 0.003 \\
\hline Docohexsanoic & 0 & 0 & 0.007 & \pm & 0.001 \\
\hline SFA & 65.2 & & 46.21 & & \\
\hline MUFA & 28.52 & & 38.43 & & \\
\hline PUFA & 0.933 & & 3.347 & & \\
\hline
\end{tabular}

The Profile of Fatty Acid Ice Cream that Fortified with Microcapsules Contains of Trevally with Catfish Fish Oil.

The results of this analysis can be used to determine the changes that occur in the fatty acid composition. The Profile of Polyunsaturated Fatty Acids (PUFAs), Monounsaturated Fatty Acids (MUFA) and Saturated Fatty Acids (SFA) of the ice cream that fortified with microcapsules contains of trevally with catfish fish oil are presented in Table 4 . The data in Table 4 explained that the ice cream that has been fortified with microcapsules mixture between trevally and catfish fish oil, is dominated by Saturated Fatty Acids (SFA), Monounsaturated Fatty Acids (MUFA) and Polyunsaturated Fatty Acids (PUFAs). After it has been fortified, the Saturated Fatty Acids (SFA) concentration decreased. On the other hand, MUFA and PUFA concentration was increasing. Therefore, from the aspect of health, fortified ice cream using microcapsules mixture between trevally and catfish fish oil, could be consider to give good influence and potential as a functional ice cream.

Reduce the amount of some specific saturated fatty acids, especially myristic acid (C14: 0) and palmitic acid 
(C16: 0) might be increasing the amount of oleic acid vasenatacid and rumenatacid is a particular target, which could improves the

\section{CONCLUSION}

It can be concluded that freeze drying method from the point of view of total PUFA is the best method for

\section{REFERENCES}

Adesola, O. O. 2011. Comparative Study of Proximate Composition, Amino and Fatty Acids of Some Economically Important Fish Species in Lagos, Nigeria. African Journal of Food Science., 5(10): 581-588

Anwar, S.H., and Kunz, B. 2011. The Influence of Drying Methods on the Stabilization of Fish Oil Microcapsules: Comparation of Spray Granulation, Spray Drying, and Freeze Drying. Journal of Food Engineering, 105: 367-378

AOAC. 2000. Offical Methods of Analysis of the Association of Official Analysis. $18^{\text {th }}$ Edn. Association of Offical Analytical Chemists. Washington D.C.

AOCS. 1990. Offical Methods and Recommended Practises of the America Oil Chemistry Society, 4ed. Champaign, Illinois.

Astuti, Y. dan T. Setyawardani. 2006. Pengunaan Susu Skim dan Asam Lemak Essensial sebagai Alternatif Cara Memperbaiki Kualitas Nutrisi Yoghurt. Animal Production, 8: 1621.

Banning, M. 2005. The Role of Omega 3Fatty Acids in the Prevention of Cardiac Events. British Journal of Nursing, 25: 503-508. long-term health for consumers (Smet et al., 2010).

mincroencapsulation process of this fish oil mixture. Fortification of $15 \mathrm{~g} \quad(\mathrm{w} / \mathrm{w})$ microencapsulated fish oil in ice cream could reduced SFA and increased the MUFA and PUFA.

Beindorff, C.M and N.J. Zuidam. 2010. Encapsulation Technologies for Active Food Ingredients and Food Processing. Springer Science Business Media, 161-185

Day,L. M.Xv., P. Hoobin, I.. Burgar, M.A. Augustin. 2007. Characterisation of Fish Oil Emulsions Stabilised by Sodium Caseinate. Journal of Food Chemistry, 105: 469-479

De Garmo, E.P., W.G. Sulivan, and J.R. Canada. 1984. Engineering Economy, $7^{\text {th }} \quad$ Edition,Macmilan Publishing Company, New York.

Drusch, S., S. Benedetti, M. Scampicchio and S. Mannino. 2008. Stabilisation of Omega 3-Fatty Acids by Microencapsulation. Agro Food Industry Hi-Tech, 9: 31-32.

Estiasih, T., Kgs. Ahmadi, dan C. Choirun. 2008. Karakteristik Mikrokapsul Minyak Kaya Asam Lemak Omega 3 dari Hasil Samping Penepungan Lemuru. Jurnal Teknologi dan Industri Pangan, 19 (2): 121-129.

Estrada ， J.D. 2011. Developing a Strawberry Yoghurt Fortified with Marine Fish Oil. Journal of Dairy Science, 94: 5760-5769.

Gobel, M. 2012. Inovasi Pengembangan Sosis Ayam Fungsional yang Diformulasi dengan Campuran Minyak Ikan Selar (Selaroides $s p$ ) dan Lele (Clarias sp). Disertasi Program Doktor Ilmu Ternak. Pasca Sarjana Fakultas Peternakan UB. Malang. 
Heinzelmann, K., K. Franke, B. Jensen and A.H. Haahr. 2000. Protection of Fish Oil From Oxidation by Microencapsulation Using Freezedrying Techniques. Journal Lipid Sciences Technology, 4: 114-121.

Hogan S.A., B.F. .McNamee, E.D. O'Riordan, and M. O'Sulivan, 2001. Microencapsulation Properties of Whey Protein Concentrate. Journal of Food Science, 66: 675-680

Kolanowski, W. and G. Laufenberg. 2006. Enrichment of Food Products with Polyunsaturated Fatty Acids by Fish Oil Addition. European Food Research and Technology, 222: 472477.

Let, M.B., C. Jacobsen, and A.S. Meyer. 2003. Effect of Fish Oil Type, Lipid Antioxidants and Presence of Rapeseed Oil On Oxidative Flavour Stability of Fish Oil Enriched milk. European Journal of Lipid Science and Technology, 106: 170-182.

Luczynska, J. B., Paszczyk, Z., Borejsco. L. and Tarkowski. 2012. Fatty Acid Profile of Muscles of Freshwater Fish from Olsztyn Markets. Polish Journal
Food Nutrition Science , 60 (1): 5155.

Nowsad, A. K. M., B.P. Mchanthy, M. Enamul and H. Shakuntala. 2012. Nutritional value, consumption and utilization of Hilsa (Tenuolailisha). Proceeding Regional on Hilsa :Potensial of Aquaculture, Dhaka, Bangladesh.

Nurnaida, A. A., A. Azrina, I. Amin, S. M. Alinafiah and R. R. Muhammad. 2013. Quantitative determination of fatty acids in marine fish and shellfish from warm of straits of Malacca for nutraceutical purposes. BioMed Research International, 2013: 1-12.

Steffens, W and M. Wirth. 2005. Freshwater Fish - An Important Source of n-3 Polyunsaturated Fatty Acid: A review. Archives of Polish Fisheries, 13 (1): 5-16.

Smet,K., D.J. Block, , P.V.D. Meeren, and K. Raes. 2010. Influence of Milk Fatty Acid Composition and Process parameters on The Quality of Ice Cream. Journal Dairy Science Technology, 90: 431-447. 